\title{
Outramente dito: a teoria da tradução de Paul Ricoeur
}

\section{Otherwise said: Paul Ricouer's transtation theory}

DOI: $10.12957 /$ ek.2018.34737

Dr. Carlos Cardozo Coelho

cardozocoelho@gmail.com

Universidade do Estado do Rio de Janeiro - UERJ

Nossa hipótese central neste artigo segue, não por acaso, uma das primeiras frases do livro de Ricoeur dedicado à questão da tradução. Nesta frase o filósofo afirma: a tradução é uma "aposta difícil e, por vezes, impossível de aceitar" (RICOEUR, 2004, p.10). Todas as interpretações vindouras serão norteadas por esta proposição, pois partiremos da premissa, de que a tradução - analogamente a comunicação - é uma aposta difícil, ou, quem sabe, impossível. Esta discussão entre o possível e o impossível, ou entre o possível, o difícil e o impossível, será o fio condutor de toda a nossa interpretação desta questão tal qual aparece na obra de Ricoeur.

\section{PALAVRAS-CHAVE \\ Tradução. Hermenêutica. Fenomenologia. \\ Linguagem. Alteridade}

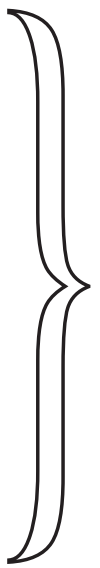

\{

Our central hypothesis in this article follows, not by chance, one of the first sentences of Ricoeur's book dedicated to the question of translation. In this sentence, the philosopher affirms: translation is a "difficult bet and, sometimes, impossible to accept" (RICOEUR, 2004, p.10). All the interpretations that follows will be guided by this proposition, because we will start from the premise that the translation - analogously to the communication - is a difficult bet, or perhaps, an impossible one. This discussion between the possible and the impossible, or between the possible, the difficult and the impossible, will be the guiding thread of our entire interpretation of this question as it appears in Ricoeur's work.

KEYWORDS Translation. Hermeneutics. Phenomenology.

Language. Otherness. 


\section{Um servo para dois amos: uma tragédia anunciada}

Para Ricoeur, a questão da tradução não é apenas um apêndice à questão geral da linguagem. Não podemos suprimir o ímpeto humano da tradução, não podemos simplesmente deixar de traduzir, pois desde que nos compreendemos, primariamente, como Dasein, ou seja, enquanto entes que se compreendem ao compreenderem o próprio mundo, estamos traduzindo, estamos interpretando. A tradução é, então, um conceito filosófico irmão de outros conceitos como o de compreensão, interpretação, comunicação, etc. Traduzir é também comunicar; comunicar é, por sua vez, uma tentativa de ser compreendido; assim como a compreensão nada mais é do que uma interpretação (por isso Ricoeur fala de dois tipos de tradução: a tradução interlinguística, ou seja, entre duas línguas diferentes; e a tradução intralinguística, que acontece no interior de uma mesma língua - deixemos esta distinção momentaneamente em suspenso).

A questão da alteridade está sempre em jogo quando tratamos destes conceitos, pois todos eles são engenhocas filosóficas construídas com a intenção de explicar o contato entre o mesmo e o outro, entre o próprio e o impróprio, entre o nativo e o estrangeiro, ou ainda, entre $e u$ e $t u, t u$ e $e u$ (e quando falamos de tradução, haverá ainda um terceiro interveniente).

A palavra francesa épreuve, que significa tanto "provação", quanto "pena sofrida", resume, segundo o hermeneuta francês, todas as dificuldades que enfrentará o tradutor diante de seu ofício. Pois ele, o tradutor, tem a difícil, ou talvez impossível, missão de transpor a barreira linguística que separa o autor estrangeiro do leitor que habita noutro campo semântico. Traduzir é "pôr à prova, como se diz, um projeto, um desejo, ou mesmo uma pulsão: a pulsão de traduzir" (ST, p.10).

A tradução é, para Ricoeur, justamente isso: uma pulsão (trieb) no sentido freudiano do termo. Ela está na ordem do desejo, do desejo de ser compreendido, do desejo de comunicação. Como diz Ricoeur no seu livro $O$ Conflito das interpretações, "Eros é filho de Poros e Pénia" (RICOEUR, s/a, p. 23), ou seja, ao ser inserida numa cadeia pulsional, a tradução aparece sincronicamente como riqueza e pobreza. Ela nos dá a esperança do acontecimento que efetiva- 
mente é, mas também a desilusão da consciência de sua efemeridade. O que acontece, então, com este desejo que se atualiza ao mesmo tempo em que, na sua fugacidade, escapa? Esta é justamente a "provação" e a "pena sofrida" pelo tradutor, que nunca poderá concluir peremptoriamente o seu desejo.

Para explicar esta provação implicada no trabalho de tradução, Ricoeur propõe uma síntese entre o pensamento de dois pensadores alemães, a saber, Benjamin e Freud:

Para explicar essa prova, sugiro que se compare a "tarefa do tradutor" de que fala Walter Benjamin com a dupla acepção que Freud atribui ao vocábulo "trabalho", quando fala num dos seus ensaios de "trabalho de memória" e, noutro ensaio, "trabalho de luto". Na tradução, também se procede a uma certa salvação e a um certo consentimento na perda. Salvação de quê? Perda de quê? (RICOEUR, 2004, p.10)

Uma dialética entre as reflexões de Benjamin e de Freud pode ser profícua quando compreendemos que o tradutor, ao dedicar-se ao seu trabalho, salvará algo deste acontecimento, um extrato do original, mas, ao mesmo tempo, perderá algo de irrecuperável, fugaz. Antes de adentrarmos propriamente nos pensamentos de Benjamin e de Freud, devemos entender quais são os atores da tradução.

Primeiramente é necessário que exista o outro, o estrangeiro. É devido à existência do estrangeiro que existe a tradução, destarte, uma filosofia que pensa a tradução tem de ser, antes de qualquer coisa, uma filosofia da alteridade. O estrangeiro que fazemos referência aqui, o autor, deve (aliás, todos os estrangeiros, mesmo os compatriotas), então, falar outra língua, além de ter escrito uma obra nesta outra língua. Por exemplo, eu traduzo - construo uma comparável, como veremos adiante - aqui o pensamento de Ricoeur, pensador que escreveu seus textos em francês, para o português. Definimos, deste modo, o estrangeiro da tradução, chamemo-lo assim, como sendo a coimplicação de todos estes termos (a obra, o autor e a sua língua).

Além do estrangeiro, existe o nativo da tradução (o leitor), aquele que não compreende linguisticamente o estrangeiro da tradução, aquele que tem outra forma de descrever e se relacionar com o mundo, ou seja, uma forma diferente de segmentar o sentido e o seu referente. E, entre estes dois, temos o tradutor que tem a difícil missão (talvez impossível) de transpor a barreira que separa o nativo do estrangeiro, o estrangeiro do nativo. 
Diante desta dupla demanda que o tradutor tem de atender, o ato de traduzir passa a ser interpretado por Ricoeur como a tentativa de "servir a dois amos: o estrangeiro na sua obra, o leitor no seu desejo de apropriação [...]. Esse paradoxo provém de uma problemática ímpar; duplamente sancionada por um voto de fidelidade e uma suspeita de traição" (RICOEUR, 2004, p.11). Este problema, clássico à hermenêutica, foi abordado pelo romântico Schleiermacher quando pensou este "paradoxo em duas fases: 'conduzir o leitor ao autor', 'conduzir o autor ao leitor"' (RICOEUR, 2004, p.11). Um servo para dois amos: uma tragédia desde o princípio, talvez desde Babel, anunciada.

\subsection{Do trabalho de memória à tarefa do tradutor}

É diante deste quiasma que, para Ricoeur, os conceitos freudianos de "trabalho de memória" e "trabalho de luto" podem encontrar sua validade teórica no que diz respeito à tradução:

Aventuro-me a aplicar a essa situação o vocabulário freudiano e a falar não só do trabalho de tradução, no sentido em que Freud fala do trabalho de rememoração, mas também de trabalho de luto (RICOEUR, 2004, p.42).

E continua Ricoeur:

Trabalho de memória, em primeiro lugar: esse trabalho que também podemos comparar a um parto, incide nos dois polos da tradução. Por um lado, ataca a sacralização da língua dita materna, os seus receios identitários (RICOEUR, 2004, p.11).

O conceito de trabalho de memória é desenvolvido por Freud no artigo intitulado "Recordar, repetir, elaborar" (1914). Neste texto, o psicanalista alemão aponta para uma oposição entre a elaboração - o trabalho de memória - e a compulsão de repetição. Enquanto o trabalho de memória leva o paciente de encontro aos seus traumas reprimidos e, consequentemente, a uma eventual "cura", que seria apenas a elaboração destes traumas no nível da consciência, a compulsão de repetição, fruto da resistência, impede que os conteúdos traumá- 
ticos inconscientes emerjam à consciência. Mas esta resistência ao inconsciente pode ser combatida.

Certamente, só o conhecemos [o inconsciente] como algo consciente, depois que ele sofreu transformação ou tradução para algo consciente. A cada dia, o trabalho psicanalítico nos mostra que esse tipo de tradução é possível. A fim de que isso aconteça, a pessoa sob análise deve superar certas resistências - resistências como aquelas que, anteriormente, transformaram o material em questão em algo reprimido rejeitando-o do consciente (FREUD [1915], 1974, v.14, p. 189).

É contra esta resistência - esta barra ao inconsciente - ao trabalho de memória que o analista deve lutar, da mesma forma, o tradutor deve enfrentar com vigor a tensão que há entre o estrangeiro, o nativo e suas respectivas línguas. Assim como o inconsciente, no neurótico, vai encontrar resistência para ser representado em palavras, o nativo da tradução (o leitor) resiste ao estrangeiro; ele teme que a nova língua possa trazer à luz do dia contradições que desestruturem e entrem em conflito com a sua língua materna.

Vejamos o que diz Ricoeur:

Essa resistência por parte do leitor não deve ser subestimada. A pretensão à autossuficiência, a recusa da mediação do estrangeiro, alimentaram inúmeros etnocentrismos linguísticos e, mais grave ainda, inúmeras pretensões à hegemonia cultural, como se pode observar por parte do latim, desde a Antiguidade tardia até ao final da Idade Média e mesmo para lá do renascimento, e também por parte do francês da época clássica e do anglo-americano dos nossos dias. Utilizei, como na psicanálise, o termo "resistência" para designar a recusa dissimulada da prova do estrangeiro por parte da língua de acolhimento (RICOEUR, 2004, p.11-12).

Entrementes, esta resistência por parte do leitor não é sem correlato, pois no caso da tradução não é apenas a língua de acolhimento que resiste, o estrangeiro também o fará (ele deve resistir, ele resistirá, pois só assim devirá 
estrangeiro), o que torna esta tarefa uma guerra contra uma dupla resistência: um servo para dois amos.

O tradutor descobre essa resistência em várias fases de sua tarefa. Descobre-a mesmo antes de começar, como presunção de não tradutibilidade, que o inibe, antes mesmo de abordar a obra. Tudo se joga, tudo se passa como se na emoção inicial, e por vezes na angústia de começar, o texto estrangeiro se erguesse como uma massa inerte de resistência à tradução. (RICOEUR, 2004, p.12).

Abramos aqui um parêntese: talvez a complexidade da analogia estabelecida por Ricoeur - não absoluta - entre o trabalho de tradução e o trabalho de memória possa ser (re)estabelecida nos termos da segunda tópica freudiana: assim como o superego ${ }^{1}$ (parte do ego que está menos firmemente vinculada à consciência) media a sempiterna tensão entre o id e o "ego consciente", entre o princípio de prazer e o princípio de realidade, o tradutor se confronta (1) com o estrangeiro que não quer ser submetido à língua do leitor, (2) com o leitor que não quer devir estrangeiro e ser dominado por seus desejos materializados num novo léxico que desorganiza a sua língua materna (um não quer o outro impondo significações em seu campo semântico), (3) com ele próprio, pois, na condição de "superego" (locado no mesmo campo semântico que o leitor, com a tarefa de transmitir algo de estrangeiro na sua própria língua) pode ser considerado um "leitor-tradutor". Dito isso, observemos com Ricoeur:

No plano psíquico, diz ele [Antoine Berman], o tradutor é ambivalente. Quer forçar dos dois lados, forçar a sua própria língua a encher-se de estranheza, forçar a outra língua a deportar-se para a sua língua materna (RICOEUR, 2004, p.17).

1 O supergo é uma diferenciação do ego que tem três funções: 1) ele é a consciência moral do ego, ou seja, é a censura; 2) a auto-observação, ou seja, o ego deve ser capaz de avaliar a si mesmo; 3) a função de "ideal do ego" que é formulada na infância com base nas figuras materna e paterna. (Cf. ANDRADE, 1984, p. 144-148). 
Com esta analogia, portanto, nos parece possível compreender que o trabalho do tradutor se defronta com a necessidade de mediar uma batalha insolúvel, ou seja, mediar aquilo que não se deixa mediar, e, porque não, para usar uma proposição aporética típica a obra de Derrida, mediar o im-mediável.

\title{
1.2. Traduzível (possível) versus intraduzível (impossível)
}

Segundo Ricoeur:

\begin{abstract}
Por um lado, essa presunção inicial [de não-traduzibilidade] não é mais do que um fantasma alimentado pela confissão banal de que o original não será reproduzido por outro original; confissão que designo por banal, por que se assemelha à do colecionador perante a melhor cópia de uma obra de arte. Esse fantasma culmina no receio de que a tradução, porque tradução, venha a ser apenas uma má tradução, de certa forma, por definição (RICOEUR, 2004, p.12-13).
\end{abstract}

Este fantasma é o grande inimigo do tradutor, é ele que deve ser enfrentado, confrontado. Diante deste "inimigo", muitas soluções foram propostas, desde a afirmação incessante de uma língua originária, de um terceiro texto - a língua perfeita - que daria sentido e iluminaria o tradutor em direção a uma verdade linguística, até o outro extremo, afirmando a impossibilidade da comunicação interlinguística. Tentemos agora entender como se dá essa disputa entre as teorias do traduzível e do intraduzível, para só depois conquistarmos o conceito de "trabalho de luto" aplicado à tradução.

Para Ricoeur, ao falarmos de tradução partimos de um ponto,

o fato considerável da universalidade da linguagem: 'todos os homens falam'; trata-se de um critério de humanidade à margem do instrumento, da instituição, da sepultura; linguagem é utilização de sinais que não são coisas, mas que valem como coisas - a troca dos sinais 
na interlocução -, o papel maior de uma língua comum no plano da identificação comunitária; ora aí está uma competência universal desmentida pelas suas performances locais, uma capacidade universal desmentida pela sua efetuação propagada, disseminada, dispersa. Daí as especulações primeiro no plano do mito e, depois, no plano da filosofia da linguagem quando se interroga acerca da origem da dispersão-confusão (RICOEUR, 2004, p.25).

Junto deste fato, "todos os homens falam", acrescenta-se outro: os homens falam, mas cada um a sua maneira. O que eles falam e acerca do que eles falam não é de forma alguma universalizável. Ao mesmo tempo em que existe uma distinção radical entre o português e o chinês, existe uma distinção entre o português do Brasil e o português de Portugal, entre o português do Recife e o português do Rio de Janeiro, entre o português da Rocinha e o português do Leblon, ou mesmo entre o português do avô e o do seu neto.

Diante do fato dos homens efetivamente falarem, mas falarem incontáveis línguas, mesmo no interior da mesma comunidade, surge uma aporia:

(...) ou a diversidade das línguas exprime uma heterogeneidade radical - e, nesse caso, a tradução é teoricamente impossível e as línguas são a priori intraduzíveis. Ou a tradução considerada como um fato explica-se por um fundo comum que possibilita o fato de traduzir, mas, nesse caso, deve poder-se redescobrir esse fundo comum, e é essa a pista da língua original, ou reconstruí-la logicamente e é essa a pista da língua universal; original ou universal, essa língua absoluta deve poder ser revelada, nos seus registros fonológicos, lexicais, sintáticos, retóricos (RICOEUR, 2004, p.27).

Retornamos assim à oposição supracitada: traduzível versus intraduzível. Ou a diversidade de línguas exprime a relação absolutamente singular entre o próprio e o impróprio, ou seja, exprime a inerente incomunicabilidade do aspecto psíquico de cada indivíduo, o qual a língua seria incapaz de vislumbrar; ou a tradução é um fato condicionado por alguma entidade mistérica, e, portanto, antes de traduzir, devemos obsecrar até a exaustão o terceiro texto que possibilitará a tradução perfeita. 
O grande problema da tradição que discutiu a tradução foi, de acordo com Ricoeur, erigir a sua reflexão sobre esta oposição: traduzível versus intraduzível. Segundo o hermeneuta francês, devemos instaurar uma nova oposição mais prática e menos teórica: fidelidade versus traição, oposição essa que se ergue sobre o conceito de equivalência sem identidade. Entretanto, não devemos ser ingênuos e crer que esta nova oposição solucionará o problema da tradução e a tornará uma tarefa menos arriscada.

\footnotetext{
É [...] essa a minha tese, no caso da tradução nas suas duas vertentes extralinguística e intralinguística: teoricamente incompreensível, mas efetivamente praticável, à custa da alternativa prática - fidelidade versus traição (RICOEUR, 2004, p.28).
}

Abordaremos esta nova oposição no final deste artigo, sigamos agora do traduzível ao intraduzível.

\subsubsection{Traduzir é impossível!}

Ao falarmos da impossibilidade da tradução partimos da

diferença das línguas, que sugere uma heterogeneidade radical que deveria a priori tornar a tradução impossível. Essa diversidade afeta todos os níveis operatórios: a divisão fonética; a divisão lexical que opõe as línguas, não palavra a palavra, mas de sistema lexical para sistema lexical [...]; a divisão sintática que afeta, por exemplo, os sistemas verbais e a situação de um acontecimento no tempo ou ainda os modos de encadeamento e de consecução (RICOEUR, 2004, p.55-56).

Entretanto, a diferença entre as línguas não está apenas no nível dos signos, mas também no das frases e dos textos. Lembremos que Ricoeur, na esteira da semântica de Benveniste, divide a linguagem em três unidades: a palavra, que diz respeito ao nível semiótico da linguagem, a frase e os textos, que dizem respeito ao nível semântico da linguagem, sendo este último, o texto, o problema central da hermenêutica. 
As línguas não são apenas diferentes pela forma como dividem o real, mas também pela forma de o recompor no nível do discurso; a este respeito, Benveniste, respondendo a Saussure, observa que a primeira unidade de linguagem significante é a frase e não a palavra. [...] É neste nível que o intraduzível se revela pela segunda vez inquietante; é não só a divisão do real, mas a relação do sentido com o referente: o que se diz na sua relação com aquilo acerca do qual se diz; as frases do mundo inteiro esvoaçam entre os homens como borboletas inacessíveis (RICOEUR, 2004, p.56-57).

Podemos explicar a tese do intraduzível e a resposta que Ricoeur dá a ela recorrendo ao estruturalismo linguístico, sobretudo na distinção apresentada anteriormente entre valor e significação, que contêm embrionariamente a distinção entre semiótica e semântica, ou seja, entre a palavra e a frase.

O valor está na língua, a significação está na fala. Pensemos no exemplo clássico no Curso de Linguística Geral, a distinção entre a palavra inglesa "sheep" e a palavra francesa "mouton". Se analisamos estas duas palavras em seus respectivos sistemas linguísticos, vemos que possuem valores distintos. "Sheep", em inglês, serve apenas para designar o carneiro, em oposição à "mutton" que é usada para designar a carne do carneiro. Por outro lado, em francês, a palavra "mouton" é usada tanto para representar um carneiro vivo quanto para indicar a carne do carneiro servida à mesa. Tanto "sheep" quanto "mouton" enunciam a mesma significação, mas não o mesmo valor, pois enquanto em inglês temos dois signos, em francês temos apenas um (Cf. CULLER. 1979). A significação expõe, então, o momento de execução e enraizamento na realidade do signo que, por sua vez, é imanente ao sistema e formal: puro valor. Significação está no nível semântico, valor estrutura o semiótico.

A partir da instauração da linguística estrutural como ciência, alguns filósofos e linguistas - estruturalistas e pós-estruturalistas - coligiram que a tradução é teoricamente impossível. Apesar das estruturas linguísticas serem universais, cada uma delas, malgrado se estruturarem analogamente, exporiam uma visão de mundo que seria incomunicável utilizando outro léxico.

Entretanto, para Ricoeur - e a crítica que ele faz a Derrida (Cf. RICOEUR, 1975) passa por aí -, estes intelectuais esqueceram que existe outro nível da linguagem que não o semiótico, a saber, o nível semântico, o nível da significação. É por isso que a distinção entre valor e significação expõe com clareza 
esse duplo movimento da crítica de Ricoeur as teorias do intraduzível. Para o hermeneuta, elas afirmariam apenas um nível da linguagem, o nível semiótico no qual o valor - que é intransponível entre os diversos sistemas linguísticos impera. Todavia, existe também a significação, que emerge no nível semântico e torna a tradução, apesar de seus riscos, uma tarefa praticável.

Se se acrescentar a ideia de que cada divisão linguística impõe uma visão de mundo, ideia a meu ver insustentável, dizendo, por exemplo que os Gregos construíram ontologias porque têm o verbo "ser" que funciona como verbo de ligação e como asserção da existência, então é o conjunto das relações humanas dos locutores de uma dada língua que revela não sobreponível ao conjunto das relações humanas que levam o locutor de outra língua a compreender-se a si mesmo ao compreender sua relação com o mundo (RICOEUR, 2004, p.30).

E continua Ricoeur,

\begin{abstract}
Nesse caso, deverá concluir-se que a falta de compreensão é legítima, que a tradução é teoricamente impossível e que os indivíduos bilíngues só podem ser esquizofrênicos (RICOEUR, 2004, p.30).
\end{abstract}

Todavia, se há algo de interdito, não será "o conjunto das relações humanas dos locutores de uma dada língua”, será o próprio aspecto psíquico (em oposição ao noético). Entretanto, a comunicação expressa, por um milagre ${ }^{2}$, o aspecto noético de nossa consciência, a saber, o psíquico subsumido ao semântico. Caso não pudéssemos transmitir em alguma medida esta experiência, aprender novas línguas seria um ato impossível. Se mesmo assim alguém aprendesse uma língua diferente da sua língua materna, deveríamos, de fato, concluir que este indivíduo tem que ter duas estruturas linguísticas sincronicamente atuantes, sendo que uma não tocaria nunca a outra.

2 Não um milagre na acepção cristã de um feito antinatural, por exemplo, Jesus transformou a água em vinho, mas no sentido de gratuidade. A comunicação (e mesmo a tradução), assim como a rosa de Angelus Silesius, é um milagre, é sem motivo, ela simplesmente acontece, ela simplesmente existe. 


\subsubsection{Traduzir é possível!}

De outro lado, temos as teorias que pregam a possibilidade da tradução irrestrita:

(...) existem estruturas ocultas que, ou possuem a marca de uma língua original, perdida que se tem que redescobrir, ou consistem em códigos a priori, em estruturas universais ou, como se diz, transcendentais, que se deve poder reconstruir (RICOEUR, 2004, p.30).

Nesta afirmação está contida uma crítica às teorias da tradução que creem na existência de estruturas universais que podem ser plenamente reconstruídas, possibilitando achar o ponto de convergência entre todas as línguas, o que permitiria que a tradução fosse alcançada com maestria. Em última instância, estas teorias não trazem grandes novidades para a história do pensamento. Essas estruturas universais que devem ser reconstruídas ocupariam o mesmo papel que os "estados de alma" ocupam na teoria aristotélica das significações. São justamente os "estados de alma" que apresentariam esta convergência entre o mundo das coisas e o mundo do discurso. Ao mesmo tempo, também está presente a crítica de Ricoeur às teorias que buscam a mítica língua adâmica - na qual as coisas e o nome das coisas estariam em plena homogeneidade -, uma língua originária que teria desmoronado com o tempo. Caberia, então, ao linguista reconstruir os traços desta língua perdida.

Seja sob o nome de estruturas universais, seja sob o nome de língua original, o que está em jogo é a busca escatológica pela Verdade linguística, pelo sucesso irrevogável da linguagem, da comunicação e da tradução.

De acordo com Aristóteles,

Os sons emitidos pela voz são símbolos dos estados de alma e as palavras escritas, simbolos das palavras emitidas pela voz $(1,16$ a 3$)$.

E continua o filósofo grego:

Assim como a escrita não é a mesma para todos os homens, as palavras faladas também não o são, enquanto os estados de alma, de que estas expressões são imedia- 
tamente os signos, são idênticos para todos, como são idênticos também as coisas de que estes estados constituem as imagens $(1,16$ a $5 \mathrm{~s})$.

Para Aristóteles, existem dois níveis que são comuns para todos os homens: o plano das coisas e o plano dos estados de alma que antecederiam o plano da linguagem, onde a confusão e a polissemia se instauram. Desta forma, para as teorias que absolutizam este tipo de crença, a boa tradução será aquela que restituirá com precisão a relação entre os estados de alma - que revelaria o plano das coisas - e o discurso que é sempre equívoco - seja falado, ou escrito.

Entretanto,

(...) ninguém pode dizer como se poderia fazer derivar as línguas naturais, com todas as bizarrias de que falaremos mais adiante, da pressuposta língua perfeita: $a$ diferença entre a língua universal e a língua empírica, entre o a priórico e o histórico, parece intransponível (RICOEUR, 2004, p.33).

É justamente neste ponto que pensar a tradução, não como mero fenômeno interlinguístico, pode ser proveitoso: estudar o percurso histórico de uma língua pode revelar com maior clareza este escolho - insuperável - entre o a priórico e o histórico. Contudo, para o hermeneuta francês, esta pulsão pela língua original também deu fruto a grandes reflexões:

A nostalgia da língua original, também gerou a poderosa meditação de Walter Benjamin ao escrever "A tarefa do tradutor" em que a "língua perfeita", a "língua pura" trata-se de expressões do autor - figura como horizonte messiânico do ato de traduzir, garantindo secretamente a convergência entre os idiomas quando estes são levados até ao cume da criatividade poética. Infelizmente, a prática da tradução não é ajudada por essa nostalgia convertida em espera escatológica; e talvez tenhamos de fazer em breve o luto do desejo de perfeição, para assumir sem embriaguez e com toda a sobriedade a "tarefa do tradutor" (RICOEUR, 2004, p.31). 
Talvez, a grande deficiência da Filosofia, pelo menos aquela que Derrida chama de falogocêntrica, seja sua impossibilidade de aceitar o fracasso constitutivo de todo projeto universalista. Aceitar a incompletude e a provisoriedade do pensamento: eis a finalidade do trabalho de luto vindo à tona. Aceitar que a tradução

(...) insere-se na longa litania dos "apesar de tudo". Apesar dos fratricídios militamos pela fraternidade universal. Apesar da heterogeneidade dos idiomas, existem bilíngues, poliglotas, intérpretes e tradutores (RICOEUR, 2004, p.34).

Tentemos agora alçar o conceito freudiano de trabalho de luto para o âmbito da tradução.

\title{
1.3. Do trabalho de luto à tarefa do tradutor: nem possível, nem impossível
}

Para Ricoeur, estas duas opções são insuficientes, pois a tradução é um fato, ela efetivamente acontece: nos comunicamos com os outros, mesmo que esta comunicação seja precária, mesmo que não exista tradução perfeita. Para o hermeneuta francês:

\begin{abstract}
(...) mal se inicia o trabalho de tradução, a resistência à tradução reveste-se de uma forma menos fantasmática. Há zonas de intraduzibilidade espalhadas pelo texto, que fazem da tradução um drama, e do desejo de uma boa tradução uma aposta (RICOEUR, 2004, p.13. O grifo é nosso).
\end{abstract}

Pensar a tradução como aposta é apontar para duas direções: primeiro uma constatação empírica, a tradução acontece, ela é um evento concreto; segundo, que ela, apesar de existir, nunca nos dará a certeza de um fim, de um fechamento. Ou seja, é pensar que a tradução não é nem possivel nem impossível, ela é uma tarefa difícil (mas de uma dificuldade que beira a impossibilidade, como ainda veremos). Diante desta dupla tensão, como podemos criar um critério para a boa tradução? 
O dilema é o seguinte: numa boa tradução, os dois textos, de partida e de chegada deveriam ser avaliados por um terceiro texto inexistente. O problema, de fato, é dizer a mesma coisa, ou pretender dizer a mesma coisa, de duas formas diferentes. Todavia, essa mesma coisa, essa coisa idêntica não surge em parte alguma como um terceiro texto cujo estatuto seria o do terceiro homem do Parménides de Platão, terceiro entre a ideia do homem e os modelos humanos que se pressupõe participarem na ideia de verdade e real (RICOEUR, 2004, p.15).

E continua Ricoeur na página seguinte:

À falta desse terceiro texto, em que residiria o próprio sentido, o idêntico semântico, o único recurso que existe é a leitura crítica de alguns especialistas senão poliglotas, pelo menos bilíngues, leitura crítica que equivale a uma retradução privada (RICOEUR, 2004, p.16).

A difícil aposta da tradução pode ser resumida numa máxima: traduzamos e retraduzamos incansavelmente! É por isso que a tradução será sempre uma aposta difícil, não há um critério absoluto para bem traduzir, o que está explicitado no fato de sempre haver retraduções dos grandes textos da humanidade: da Bíblia aos textos de Homero, de Platão à Heidegger. Os textos nunca encontraram, nem encontrarão, uma tradução definitiva.

Tal como para o Platão do Parménides, não há terceiro homem entre a ideia do homem e um homem em especial, $[\ldots]$ também não há terceiro texto entre o texto de partida e o texto de chegada. (RICOEUR, 2004, p.41).

A falta deste terceiro texto (seja sob o nome de estruturas universais, língua perfeita etc.), que seria portador do sentido idêntico entre o texto de chegada e o texto de partida, junto da melancolia do tradutor diante da ausência deste texto, nos conduzirá à conquista do conceito psicanalítico de "trabalho de luto" transposto para o âmbito da tradução - conceito este que vem assombrando este trabalho desde o princípio. 
No texto "Luto e melancolia", Freud define o luto como a reação à perda de uma pessoa querida ou de uma abstração que esteja no lugar dela, como pátria e ideal, por exemplo (Cf. Freud, 2011, p.47); outrossim, define a melancolia como um desânimo profundamente doloroso, uma suspensão do interesse pelo mundo externo, perda da capacidade de amar, inibição de toda a atividade e um rebaixamento do sentimento de autoestima, que se expressa em autorrecriminações e autoinsultos, chegando até a expectativa delirante de punição (Cf. Freud, 2011, p.47).

Segundo Freud, o luto e a melancolia se configuram como quadros clínicos semelhantes, contudo, enquanto no luto existe uma causa determinada, isto é, a perda concreta de algum objeto, dando origem a certa temporalidade em que o indivíduo fica incapacitado de eleger outro objeto amoroso, a melancolia se prende mais à perda de "algo" de natureza idealizada e abstrata. Freud assinala que a melancolia, nos casos extremos, corrói tanto no indivíduo a sua autoestima que pode conduzir ao suicídio (literal, mas também simbólico). Mas o que esta reflexão sobre o trabalho de luto e o trabalho de melancolia pode nos acrescentar no que diz respeito à tradução?

O fantasma da origem tornada histórica, a recusa desesperada da condição humana real, que é a da pluralidade a todos os níveis da existência; pluralidade, de que a diversidade das línguas é a manifestação mais perturbadora: porquê tantas línguas? Resposta: é assim (RICOEUR, 2004, p.60).

Ora, esta constatação empírica da multiplicidade de línguas e da provisoriedade das traduções (mostrada claramente pela retradução incessante que sofrem as grandes obras da humanidade), aliada à perda do ideal de tradução e da língua perfeita - pois a perda de um ideal é uma das condições para assunção do luto, mas também da melancolia -, pode conduzir a estados melancólicos de pensamento em que o sujeito vai se sentir empobrecido e mesmo indigno pelo fato de não conseguir acessar esta língua originária, a língua pura. É justamente neste ponto que o trabalho de luto encontra sua validade teórica no âmbito da tradução, porquanto o tradutor pode, em dado momento de ultrapassagem do luto, eleger um novo objeto de amor que não mais o ideal da língua perfeita.

Segundo Ricoeur, o messianismo de Benjamin, malgrado não crer na universalidade de uma tradução, tem como critério para a boa tradução a busca por uma linguagem em geral, ou melhor, a busca da "Linguagem em Geral". "A fi- 
nalidade da tradução consiste”, profere Benjamin, "em expressar o mais íntimo relacionamento das línguas entre si" (Benjamin, 2011, p.106). "Neste caso, o que se pretenderia atingir seria a linguagem pura, como diz Benjamin, que qualquer tradução traz consigo como seu eco messiânico" (RICOEUR, 2004, p. 19).

Além de estar presente no pensamento do filósofo judeu, o ideal da língua e também da tradução - perfeita esteve constantemente presente no romantismo alemão, na crença do absoluto:

Regeneração da língua de chegada, segundo Goethe, potencialização da língua de partida por Novalis, convergência do duplo processo Bildung que age de um e de outro lado, em von Humboldt. Ora, este sonho não foi totalmente ilusório, na medida em que encorajou a ambição de revelar a face oculta da língua de partida da obra a traduzir e, reciprocamente, a ambição de despotencializar a língua materna, convidada a pensar em si mesma como uma língua entre outras e, em último caso, a sentir-se ela própria como estrangeira (RICOEUR, 2004, p.18).

De acordo com o hermeneuta francês, este messianismo de Benjamin o conduziria a um pensamento melancólico ${ }^{3}$, assim como o conceito de absoluto conduziria os românticos à busca, quase vã, por uma língua inalcançável.

Trabalho de tradução, conquistado com a oposição de resistências íntimas motivadas pelo medo, e mesmo pelo ódio ao estrangeiro, considerado uma ameaça para nossa própria identidade linguística. Mas também trabalho de luto, na renúncia do próprio ideal de tradução perfeita. Ideal que, na verdade, não só alimentou o desejo de traduzir e, por vezes, o prazer de traduzir, mas também foi a desgraça de um Hoderlin, destruído pela sua ambição

\footnotetext{
3 Esta constatação que Ricoeur faz do messianismo de Benjamin é muito mais problemática do que aparenta à princípio. Podemos interpretar, como o faz Ricoeur, que a espera messiânica de Benjamin é uma espera por um ideal de perfeição que se concretizará, seja quando afirma a espera por uma linguagem pura, seja quando, nas teses sobre a história, espera pela redenção de todas as vozes caladas pelo materialismo histórico e sua concepção da grande História. Mas nestes mesmos textos podemos abrir margem para pensar que este horizonte messiânico nunca se concretizará, permanecendo desde o princípio apenas como horizonte, apenas como mirada, visada, nunca como fechamento. Como não pretendemos dissertar profundamente sobre o pensamento de Benjamin, deixamos a procura por esta resposta ao leitor.
} 
de fundir a poesia alemã e a poesia grega numa hiper-poesia em que a diferença dos idiomas seria abolida. [...]. Renunciar ao sonho da tradução perfeita continua a ser a confissão da diferença insuperável entre o que é nosso e o que é estrangeiro (RICOEUR, 2004, p.42-43).

E, reiterando sua posição algumas páginas à frente, Ricoeur afirma:

contribuir-se-ia para essa mitigação sugerindo que se pusesse de parte o sonho da tradução perfeita e confessando a diferença insuperável entre o próprio e o estranho (RICOEUR, 2004, p.63).

Então, o horizonte possível diante desta embasbacante perda de objeto provocada pelo choque entre o ideal fugaz e o princípio de realidade, que expõe ao ego a impossibilidade da tradução perfeita, absoluta, seria fazer o trabalho de luto. "A prova da realidade mostrou que o objeto amado já não existe mais e agora exige que toda a libido seja retirada de suas ligações com esse objeto" (Freud, 2011, p.49). Resumindo o paradoxo, Ricoeur afirma: "renunciar ao ideal de tradução perfeita. Só essa renúncia permite viver, como uma deficiência aceite, a impossibilidade, atrás enunciada, de servir a dois amos: o autor e o leitor" (RICOEUR, 2004, p.17).

Assim, o prazer da tradução se encontra justamente na aceitação desta tarefa infinita que é traduzir. Abrindo mão do absoluto linguístico e tendo como critério não a busca escatológica pela Verdade, pelo Ser (maiúsculo) da Linguagem,

o tradutor é recompensado pelo reconhecimento do estatuto intransponível de dialogicidade do ato de traduzir como horizonte racional do desejo de traduzir. A despeito da agonística que dramatiza a tarefa do tradutor, este pode sentir o prazer com aquilo a que gostaria de chamar hospitalidade linguística. [...] Hospitalidade linguística portanto, em que o prazer de habitar a língua do outro é compensado pelo prazer de receber em sua casa, na sua própria morada de acolhimento, a palavra do estrangeiro (RICOEUR, 2004, p.20-21). 
Ora, pensar a tradução como hospitalidade linguística não é instaurá-la não mais como um mero problema de linguagem, mas como um problema ético? Este será um dos temas da próxima parte do texto. Sigamos em frente e analisemos a tradução sobre outra visada.

\section{Antes e depois de Babel - da ausência à presença de um Pai}

Estamos, por constituição e não por acaso que seria um erro, “depois de Babel” (RICOEUR, 2004, p.160).

O título deste segmento (antes e depois de Babel) faz referência a duas teorias da tradução: traduzível versus intraduzível, possível versus impossível. De um lado temos as teorias pré-babélicas que, na ausência de um Pai para proferir Babel, pensam a tradução como um dado simples e inequívoco. De outro lado temos um momento pós-babel que, diante da confusão instaurada por este Pai, nos conduz à crença da impossibilidade da comunicação, seja com o estrangeiro, seja com o nativo.

Mas antes de interpretarmos o mito de Babel, vale lembrar que, segundo Ricoeur, há duas formas de abordar o problema da tradução. A primeira, e mais tradicional, diz respeito à forma como viemos tratando a tradução até aqui, a saber, pensar a relação entre duas línguas distintas. A segunda diz respeito ao problema hermenêutico por excelência: a interpretação. Podemos pensar, desta forma, a tradução não como um problema interlinguístico, mas também como problema intralinguístico, ou seja, pensar a tradução como uma província da interpretação no interior da mesma comunidade linguística.

De um lado abordamos a tradução como transposição de um texto entre duas línguas, de outro nos confrontaremos com uma questão: compreender é traduzir? Tomamos aqui um caminho diferente do tomado por Ricoeur no livro Sobre a tradução, no qual pensou primeiramente a relação entre o nativo e o estrangeiro e a diversidade das línguas, para só depois, através das dificuldades levantadas por este primeiro momento, pensar a tradução também como problema intralinguístico. No capítulo anterior já antecipamos este problema, mas agora podemos retomá-lo outramente. 
E foi toda a terra (tendo) uma língua e mesmas palavras. E foi viajando do oriente que acharam um vale na terra de Shinar, e ficaram ali. E disse cada varão a seu companheiro: Vinde, façamos tijolos e os cozinhemos no fogo. E foi para eles o tijolo por pedra e o barro por argamassa. E disseram: Vinde, edifiquemos para nós cidade e torre, e que seu cume chegue aos céus, e faremos nós fama, para que não sejamos espalhados sobre a face de toda a terra. E desceu o Eterno para ver a cidade e a torre que edificaram os filhos dos homens. E disse o Eterno: "Eis um mesmo povo, e uma mesma língua para todos eles; isto foi que os fez começar a fazer; e agora não lhes será privado tudo quanto intentam fazer. Vinde, desçamos e confundamos ali sua língua, para que não entenda cada um a linguagem de seu companheiro." E os espalhou o Eterno dali sobre a face de toda a terra, e cessaram de edificar a cidade. Por isso, chamou seu nome Babel, pois ali confundiu o Eterno a língua de toda a terra; e dali espalhou-os o Eterno sobre a face de toda a terra, Estas são as gerações de Sem: Sem tinha cem anos, quando gerou a Arpach'shad, dois anos depois do dilúvio. E viveu Sem, depois de gerar a Arpachshad, quinhentos anos, e gerou filhos ${ }^{4}$.

A tradução aqui adotada está próxima da versão citada por Ricoeur (mais próxima que a tradução citada em nota pelo tradutor do livro do hermeneuta), todavia, há uma diferença crucial, para nossa interpretação, no nome dado pelo Eterno a cidade nas duas versões. Em português na edição que usamos traduz-se o nome próprio da cidade apenas por "Babel". Em contrapartida, em francês, traduz-se por Bavel-confusion, tradução esta que mantêm a tensão presente no hebraico entre o nome próprio Babel que pode significar também confusão.

Uma discussão em torno deste nome - que nomeia e ao mesmo tempo dissemina - pode ser muito interessante (e aqui não é mais a voz de Ricoeur que ecoa). Babel pode ser entendida como confusão, mas a palavra Babel também

4Gênesis 11 Nôach, Torá - A Lei de Moisés, trad. Meir Matzliah Melamed. São Paulo: Editora Sêfer, 2001. 
pode ser entendida, caso seja dividida em duas palavras na linguagem Babilônica (Bab-El), como "Porta de Deus". Ou seja: este nome que nomeia dispersando é também o nome de Deus, o nome que dá acesso a Deus. Ora, dizer que acedemos a Deus por meio da confusão não é dizer em alguma medida que Deus é da ordem do inacessível? Não é dizer que o homem não deve tentar alcançá-lo, pois ele é o próprio nome do inalcançável, do intangível? Este Nome dá acesso ao mesmo tempo que confunde, abre caminho para interpretações, ao mesmo tempo que as dissemina.

A missão deste artigo talvez seja transmitir uma interpretação do mito de Babel para o âmbito da tradução. Mostrar como a ausência de um Pai para dizer "Babel" pendeu contra as teorias da língua perfeita (e aqui devemos ressaltar o lugar estranho que a reflexão de Benjamin ocupa nesta divisão, se é que é possível enquadrar o pensamento dele nestes termos). Caminhemos, enfim, à interpretação de Ricoeur do mito de Babel.

\subsection{Após Babel, compreender (e comunicar) é traduzir}

Segundo o hermeneuta francês, não podemos interpretar o mito de Babel como um castigo infligido por um Deus vingativo, que não quer o sucesso humano em conquistar uma língua universal ou, em ultima instância, divina. Para ele, devemos interpretar este mito

(...) como a constatação de uma separação original. Podemos começar, no início do Gênesis, com a separação dos elementos cósmicos que permite que uma ordem emerja do caos, continuar com a perda da inocência no Éden, que caracteriza igualmente o acesso à idade adulto e responsável, e passar em seguida - o que muito nos interessa para uma releitura do mito de Babel - pelo fratricídio, o assassínio de Abel, que converte a própria fraternidade num projeto ético e já não num mero dado da natureza. Se adotarmos esta linha de leitura, [...] a dispersão e a confusão das línguas, anunciadas pelo mito de Babel, vêm coroar essa história da separação, transbordando-a para o seio do exercício da linguagem. (RICOEUR, 2004, p.35).

É por isso que pensamos as teorias da língua perfeita como línguas pré-babélicas, elas não fariam justiça ao ensinamento que este mito dá acerca da 
nossa relação com a "Alteridade Absoluta" (Deus), e, por conseguinte, com a nossa própria linguagem. Defender a tradução perfeita é, de certa forma, estar ainda no vale de Shinar e engajar-se na construção da Torre de Babel.

De outro lado, as teorias que pregam a impossibilidade da comunicação e, por conseguinte, da tradução, são teorias que radicalizaram o ensinamento dado por este mito, teorias que passaram pelo détour Babel:

É assim que nós somos, é assim que nós existimos, dispersos e confusos, e chamados a quê? Pois bem... à tradução! Existe um após-Babel, definido por "a tarefa do tradutor", para utilizar o título já evocado do famoso ensaio de Walter Benjamin (RICOEUR, 2004, p.35-36).

Segundo Ricoeur, este após Babel nos conduz a uma nova máxima: "compreender é traduzir". Ou seja, em qualquer diálogo, mesmo com aqueles que falam a minha língua, a tradução estará em jogo não apenas como um problema linguístico, mas também enquanto problema ético. O que é a ética se não o ramo da filosofia que pensa a relação entre o eu e o outro? Na nossa própria comunidade existem outros, diversos outros, que não se reduzem a participar de uma mesma identidade que faria essa comunidade.

Destarte, pensar a tradução depois de Babel é lidar com este interdito instaurado pela palavra do Eterno. Outrossim, este interdito nos conduz a pensar a tradução como problema intracomunitário, pois no interior da nossa própria língua

(...) é sempre possível dizer a mesma coisa de outra for$m a$. É o que fazemos quando definimos uma palavra por outras do mesmo léxico [...]. Mas é também o que fazemos quando reformulamos um argumento que não foi compreendido [...]. Ora, dizer a mesma coisa de outra forma - autrement dit - é o que fazia ainda há pouco o tradutor de língua estrangeira (RICOEUR, 2004, p.46).

E continua Ricoeur:

Reencontramos assim, no interior da nossa comunidade linguística, o mesmo enigma do mesmo, do próprio sig- 
nificado, o sentido idêntico impossível de repetir, que se pressupõe tornar equivalente as duas versões do mesmo discurso (RICOEUR, 2004, p.46).

Vemos aqui o mesmo problema colocado pela tradução sob outra visada. Nossa hipótese afirma (com Ricoeur) não apenas que "compreender é traduzir", mas que comunicar é traduzir:

Ao mesmo tempo lança-se uma ponte entre a tradução interna, chamemos-lhe assim, e a tradução externa, ou seja, no interior da mesma comunidade, a compreensão exige, pelo menos, dois interlocutores: não são certamente estranhos, mas já são outros, outros próximos, se assim se quiser; é por isso que Husserl, ao falar do conhecimento de outrem, chama ao quotidiano der Fremde, o estrangeiro. Há estrangeiros em todos os outros. É com mais do que um que se define, se reformula, se explica, se procura dizer a mesma coisa de outra forma (RICOEUR, 2004, p.46-47).

Dizer a mesma coisa de outra forma é uma das definições possíveis para as figuras de linguagem: em vez de dizer que alguém é corajoso, podemos dizer que ele é um leão.

\subsection{Conclusão: como traduzir aquilo que é intraduzível?}

Depois de expostos todos os problemas apresentados por Ricoeur - do traduzível ao intraduzível -, tentaremos expor quais são os melhores critérios para o labor do tradutor.

\subsubsection{Traduzir, compreender e explicar}

Como apresentamos noutro artigo (Cf. CARDOZO COELHO, 2013), o movimento da hermenêutica de Ricoeur é dividido em três momentos: num primeiro há uma compreensão ingênua do texto enquanto um todo; num segundo explicamos este texto da parte para o todo; num terceiro alcançamos uma compreensão mais profunda e elaborada do texto, novamente partindo do todo. 
Para uma exposição da dialética de explicação e compreensão enquanto fases de um único processo, proponho descrever esta dialética, primeiro, como um movimento da compreensão para a explicação e, em seguida, como um movimento da explicação para a compreensão. Da primeira vez, a compreensão será uma captação ingênua do sentido do texto enquanto todo. Da segunda, será um modo sofisticado de compreensão apoiada em um procedimento explicativo. [...] A explicação surgirá, pois, como a mediação entre dois estádios da compreensão. Se se isolar deste processo concreto, é apenas uma simples abstração, um artefato da metodologia. (RICOEUR, 1995, p. 120)

Chamamos este movimento interminável, pois nunca há um fim quando se fala em compreensão e interpretação, de militante. A teoria da tradução de Ricoeur não é diferente, ela defende este mesmo movimento:

Estas considerações levam-me a afirmar que a tarefa do tradutor não vai da palavra para a frase, para o texto, para o conjunto cultural, mas no sentido inverso: impregnando-se de amplas leituras do espírito de uma cultura, o tradutor volta a descer do texto para a frase e a palavra. O último ato, se assim se pode chamar, a última decisão, tem a ver com o estabelecimento de um glossário ao nível das palavras; a escolha do glossário é a última prova em que se cristaliza, de certa forma in fine, o que deveria ser uma impossibilidade de traduzir (RICOEUR, 2004, p.57-58).

Ricoeur transporta, assim, sua teoria hermenêutica para o âmbito da tradução: ao traduzirmos devemos sempre partir de uma compreensão geral da obra e do campo semântico que a cerca; depois deste movimento de compreensão inicial do texto devemos seguir o caminho contrário, a saber, traduzir as palavras - as partes do texto - para só depois chegar ao todo. Este mesmo movimento pode ser encontrado também na interpretação que Ricoeur faz da metáfora.

De um lado, a compreensão da metáfora - entendida como obra em miniatura - possibilita a compreensão de uma obra mais longa, vale dizer, uma obra 
literária. De outro, a compreensão de uma obra literária como um todo, permite que entendamos com maior clareza a "natureza", se é que se pode falar nestes termos, da própria metáfora. O que está aí em jogo é o movimento já secular da hermenêutica, a saber, aquele da compreensão e da explicação.

No primeiro momento temos uma compreensão ingênua da metáfora (e da obra), num momento de hiato temos a explicação desta metáfora que enriquecerá a compreensão do texto como um todo. Com este processo, podemos alcançar um modo mais sofisticado de compreensão o qual Ricoeur chama de interpretação. É este último que dá a chave para a compreensão da metáfora.

\begin{abstract}
Se então nós aplicamos a explicação ao sentido, enquanto desenho imanente da obra, nós podemos reservar a interpretação o direito de investigação consagrado ao poder de uma obra de projetar um mundo próprio e de colocar em movimento o círculo hermenêutico que engloba, por sua vez, a apreensão destes mundos projetados e o avanço da compreensão de si na presença destes mundos novos (RICOEUR, 2010, p. 103).
\end{abstract}

Continua Ricoeur:

\begin{abstract}
Nossa hipótese de trabalho nos convida por consequência a proceder da metáfora ao texto no nível do sentido e da explicação do sentido - em seguida do texto à metáfora no nível da referência da obra à um mundo e à um si, isto é, no nível da interpretação propriamente dita (RICOEUR, 2010, p. 103).
\end{abstract}

\title{
2.2.2. Da fidelidade à traição: o paradigma da equivalência sem identidade
}

Retornemos, enfim, ao dilema do tradutor, vale dizer, o dilema da fidelidade versus traição. Para Ricoeur, ao traduzirmos, ou seja, ao realizarmos uma aposta, devemos ter ciência de que estamos jogando um jogo arriscado, um jogo no qual não há vitoriosos, mas apenas derrotados, pois não há tradução vitoriosa, mas apenas retraduções, reelaborações, para usar o termo freudiano. Ter ciência de que se está neste jogo é assumir que o tradutor nunca conseguirá atender aos seus dois amos - o estrangeiro e o nativo - plenamente. Resumamos, com Ricoeur: 
(...) o dilema prático entre fidelidade e traição: uma boa tradução só pode visar uma equivalência presumida, não baseada numa identidade de sentido demonstrável, uma equivalência sem identidade. Pode-se então ligar a essa presunção de uma equivalência sem identidade o trabalho da tradução, que se manifesta no fato da retradução que se observa ao nível dos grandes textos da humanidade (RICOEUR, 2004, p. 61-62).

O tradutor, diante do texto e de seu sentido, deve então pensar a tradução como uma tarefa de alcançar esta equivalência sem identidade. Apresentamos (Cf. CARDOZO COELHO, 2013) a teoria hermenêutica de Ricoeur e defendemos que o sentido nunca é apreendido enquanto fim, ou seja, a compreensão nunca para de estar em curso, pois o sentido é, por definição, polissêmico e mutante: um sentido nunca está só e nunca permanece o mesmo, não podemos alcançar algo como um sentido em absoluto, seja de uma tradução, seja de qualquer enunciado.

O que foi apesar de tudo presumido, sob a expressão aparentemente modesta de equivalência sem identidade, é a existência prévia desse sentido que se presume que a tradução "restitua", como se diz, com a ideia confusa de uma "restituição". Essa equivalência só pode ser procurada, trabalhada, presumida. É essa presunção que deve ser posta e causa. (RICOEUR, 2004, p. 63).

Esta equivalência de sentido que deve ser buscada - mas não alcançada definitivamente - entre as línguas de chegada e de partida é, segundo Ricoeur, a tentativa de construir comparáveis, elos que liguem estas duas alteridades absolutas - que, por serem alteridades absolutas, nunca se tocam plenamente. Ora, construir comparáveis

(...) não foi o que aconteceu em diversas épocas da nossa própria cultura, quando a Bíblia hebraica foi traduzida pela primeira vez para o grego, naquilo que designamos por Versão dos Setenta. E São Jerónimo reincide com a Vulgata, construção do comparável latino. [...] Para nos maternos no domínio bíblico, pode afirmar-se que Lutero 
não só construiu um comparável ao traduzir a Bíblia para o alemão [...], mas que também criou a língua alemã, como comparável ao latim, ao grego da Versão dos Setenta e ao hebraico da Bíblia (RICOEUR, 2004, p. 67).

Dentro do nosso campo semântico a tradução não se torna um grande obstáculo, pois as comparáveis já estão dadas, a equivalência já foi construída pelas traduções das grandes obras. Traduz-se Dasein por presença, arêtê por virtude, trieb por pulsão; apesar dos diversos problemas presentes nestas traduções institucionalizadas, tudo acontece com grande naturalidade.

Porém, como podemos pensar a tradução entre duas línguas muito distantes? Como traduzir, por exemplo, do grego para o chinês? É um trabalho muito mais árduo, as comparáveis ainda não estão estabelecidas, pois o chinês contém uma carga cultural diferente da nossa, herdeiros do grego. Os fantasmas do intraduzível, do secreto, do indizível, da utopia, se mostram aí com grande virulência.

A construção de comparável passou mesmo a ser a justificação de uma dupla traição, na medida em que os dois mestres incomensuráveis foram tornados comensuráveis pela tradução-construção (RICOEUR, 2004, p. 67-68).

Vale lembrar que toda tradução-construção está sujeita a desconstrução por uma nova tradução. É o mesmo movimento da metáfora: ela é uma inovação semântica que reorganiza o sistema linguístico, reconstruindo-o ao mesmo tempo em que muda as relações entre os signos, ou seja, ao mesmo tempo em que os desconstrói.

Essa construção faz-se ao nível do "sentido". "Sentido", a única palavra que não comentamos, porque foi por nós presumida. Ora, o sentido é arrancado à sua unidade como a carne das palavras, essa carne a que se chama a "letra" (RICOEUR, 2004, p. 68).

Mais uma vez a metafisica da presença aparece. Tradutores que pensam o sentido como o único guia da tradução, em detrimento da letra, da carne, são aqueles que fogem da "vergonhosa tradução literal". Estes tradutores estão antes de Babel, mas de outra forma, são aqueles que pensam a língua como sentido apenas e creem na submissão do corpo à alma. Eles esqueceram do en- 
sinamento de "Hoderlin, de Paul Celan e, no domínio bíblico, de Meschonnic" (RICOEUR, 2004, p. 68), que fizeram campanha contra estes teóricos que têm como único critério para a tradução o sentido.

A imensa maioria dos tradutores resiste, talvez no estilo salve-se-quem-puder, sem reconhecer que traduzir apenas o sentido é renegar uma aquisição da semiótica contemporânea, a unidade do sentido e do som, do significado e do significante (RICOEUR, 2004, p. 68-69).

Enfim, para Ricoeur, traduzir é, ao término do luto do ideal de tradução perfeita que nos conduz Babel, construir uma equivalência sem identidade, mas não apenas uma equivalência de sentido, mas também uma equivalência ao nível da letra, da carne, ou seja, traduzir é dizer outramente.

Recebido em: 05.06.2018| Aprovado em: 04.09.2018 $R$ eferência Bibliográfica

ARISTÓTELES. Poética. trad. br. Eudoro de Souza. in: Os pensadores. v.4 trad.port. São Paulo: Abril, 1973

AUSTIN, J. L. Quando dizer é fazer : palavras e ação, Porto Alegre : Artes Médicas, 1990

BENJAMIN, W. O anjo da história. trad. port. João Barrento. Lisboa: Assírio e Alvim, 2010

BENVENISTE, É. La forme et le sens dans le langage, Genève: La Baconnière, 1967

Pontes, 2005

Problemas de linguística geral I, Campinas:

CARDOZO COELHO, C. "Fenomenologia $e$ hermenêutica: a crítica de Paul Ricoeur à Martin Heidegger", in: Ensaios Filosóficos, v.9, p. 40-56, 2014.

CUlLER, J. As idéias de Saussure, São Paulo:
Cultrix, 1979

FREUD, S. (1974). Obras completas. Edição Standard brasileira. Rio de Janeiro: Imago, 1974. 23v. Especificamente: V.12 Recordar, repetir, elaborar [1914]; V.14 O incosciente [1915];

GREIMAS, A.J./ COURTÉS, J., Dicionário de semiótica, São Paulo: Contexto, 2008

JARDIM ANDRADE, R. “Compreensão e explicação nas ciências do espírito: a epistemologia de Wilhelm Dilthey". In: L. Miranda Hühne. (Org.). Filosofia e Ciência. Rio de Janeiro: UAPÊ, 2008 “O discurso freudiano", $1^{\text {a }}$ parte da tese de mestrado A contribuição da psicanálise para uma nova compreensão da existência, segundo o pensamento de Paul Ricoeur, Junho de 1984, UFRJ. 
RICOEUR, P. La métaphore vive, Paris: Le Seuil, 1975 (A Metáfora Viva, São Paulo: Edições Loyola, 2000)

Du texte à l'action: essais d'herméneutique II, Paris: Le Seuil, 1986 (Do texto à acção, ensaios de hermenéutica II, Porto: Rés-Editora, s/a)

Écrits et conférences 2: herméneutique, Paris: Le Seuil, 2010.

O Conflito das Interpretações: Ensaios de Hermenêutica. trad. port. Artur Morão. Porto: Rés-Editora, s/a "Structure et signification dans le langage", in: Les cahiers de l'université du Québec, Québec: PUQ, 1970.

. Sur la traduction, Paris: Bayard, 2004 (Sobre a tradução, Lisboa, Ed. Cotovia, 2005) Teoria da interpretação.trad. port. Artur Morão. Porto: Porto Editora, 1995.

SAUSSURE, F. Cours de linguistique générale (édition critique preparée par Tullio de Mauro), Paris: Payot, 1972

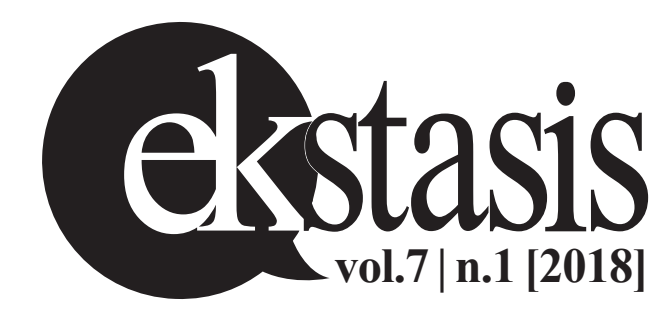

